\title{
Sarcoidosis with Polyarthritis in a Child
}

\author{
A. TH. SCHWEIZER and P. KANAAR \\ From the Departments of Paediatrics and of Dermatology, University Hospital, Leyden, Holland
}

Sarcoidosis is not a common disease in childhood, and persistent polyarthritis as a manifestation of the disease is still rarer in childhood. Although it is more common in adults (Kaplan, 1963; Katsman, 1953; Moreau, 1949; Myers, Gottlieb, Mattman, Eckley, and Chason, 1952; Regniers, 1963), we could find only 3 cases in children (Burman and Mayer, 1936; Castellanos and Galan, 1946; Zweifel, 1946).

\section{Case Report}

A boy, born January 1961, developed in July 1962 at the age of $1 \frac{1}{2}$ years palm-sized red areas with closely packed discrete papules on the skin, both shoulders, and hips ${ }^{\star}$. A punch biopsy revealed the presence of epithelioid cell granulomata. Gradually the eruption extended to the trunk and face. On the latter a butterflylike erythema appeared for a short time. Again the same histopathological picture was obtained by skin biopsy. Some time later the boy developed swelling of both ankles and ballooning of the basal phalanges of all fingers. At that time he was admitted to the paediatric department of the St. Joannes de Deo Hospital in The Hague.

The child was thoroughly examined but with essentially negative results, except for a slightly raised ESF. On account of another skin biopsy a diagnosis of sarcoidosis was considered for some time, but at discharge from the hospital after six weeks it was concluded that the boy probably suffered from an undetermined reticulosis. After discharge it was noted that he restricted the use of wrists and ankles, especially in the period after awakening. Fever, however, was never noticed. In March 1963 at the age of $2 \frac{1}{2}$ years, the child was seen for the first time in the dermatological out-patient department of the University of Leyden and a month later he was admitted to the wards.

Examination. A weak boy with normal temperature, pulse rate, and blood pressure. Pinhead-sized round, red to yellow papules were seen all over the skin of the face and body (Fig. 1). On the nose and cheeks a slight erythema with fine scaling was noted. These skin lesions apparently did not itch. The ankles, knees, wrists, and basal phalanges of the fingers were swollen

\footnotetext{
Received February 1, 1967.

* The earlier data were kindly supplied by K. H. E. P. Neering, dermatologist, who referred the patient to us.
}

(Fig. 2). These swellings were neither warm, red, nor tender, but they caused considerable impairment of the affected joints. Lymph nodes, liver, and spleen were not enlarged. There was no iridocyclitis.

Laboratory findings. Urine, normal; ESR (Westergren), $25 \mathrm{~mm} . / 1 \mathrm{hr}$; $\mathrm{Hb}, 11 \cdot 1 \mathrm{~g} . / 100 \mathrm{ml}$.; white cell count, 11.200; blood smear, no abnormalities; serum calcium, $11.2 \mathrm{mg}$. $/ 100 \mathrm{ml}$; ; serum phosphorus, $4.8 \mathrm{mg} . / 100 \mathrm{ml}$.; alkaline phosphatase (King and Armstrong), $15 \cdot 1$ units; $x$-ray films of skull, long bones, hands, knees, and chest all normal.

Tuberculin reactions (PPD $0 \cdot 1 \mathrm{mg}$.) were repeatedly negative. Serological tests for syphilis, brucellosis, histoplasmosis, and toxoplasmosis were negative, as were the antistreptolysin, Rose, latex fixation, and antinuclear factor tests. No signs of reticulosis, leukaemia, or other abnormalities were found in bonemarrow aspirates.

Two rheumatologists (Prof. J. Goslings, Prof. E. Bywaters) rejected a diagnosis of rheumatoid disease. Finally we concluded that only a biopsy of a joint capsule might help to establish a diagnosis.

Histopathology. Five punch biopsies of the skin between September 1962 and May 1963 all revealed the same picture: small rather sharply confined granulomata (Fig. 3), consisting of histiocytes, epithelioid cells, few lymphocytes, and neutrophils, and a varying number of giant cells of the Langhans type. No central necrosis was seen.

In the biopsy from the knee capsule (Fig. 4 and 5) there was a chronic proliferative, partly granulomatous inflammation, with several granulomata containing giant cells. Tissue degeneration and central necrosis was not seen. The diagnosis of sarcoidosis both of skin and joint was established.

Therapy and course. Because of the severe handicap produced by the joint manifestations, treatment was started in July 1963 with prednisone, $10 \mathrm{mg}$. daily. Within 3 weeks the papules of the skin, which had been present continuously for a year, disappeared almost completely, leaving only slightly sunken atrophic macules. The swellings of the joints diminished rapidly and after a few weeks they had regained an almost normal aspect. The boy's general condition improved considerably, and his weakness disappeared. The serum calcium returned to a normal level within 12 


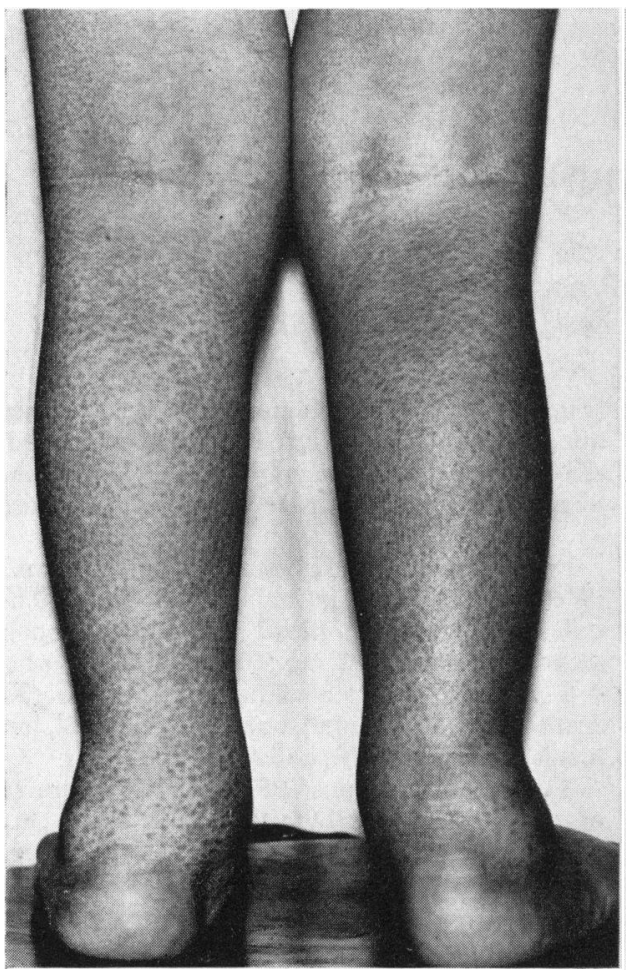

Fig. 1.-Discrete, closely situated papules on the legs.

weeks. Attempts to lower the prednisone dosage have been made several times, but each time, within 1 week, there has been recurrence of both joint and skin symptoms. Since September 1965, however, the prednisone dosage has been reduced to $5 \mathrm{mg}$. daily without relapse.

In January 1966 he developed bilateral iridocyclitis. The eye manifestations were treated with corticosteroids locally. Somatic growth and development has so far been normal.

Later in 1966 his younger brother also developed sarcoidosis of the skin.

\section{Discussion}

The similar histopathology of the joint and skin lesions appeared to justify the diagnosis of sarcoidosis. At first, however, this diagnosis seemed unlikely in view of the age of the patient, the involvement of the joints, and the clinical appearances of the skin lesions.

Age of the patient. Kendig (1962) and McGovern and Merritt (1956) could trace only 30 patients under the age of 9 years, the youngest was 2 months old.

Involvement of the joints. Besnier (1889) men-

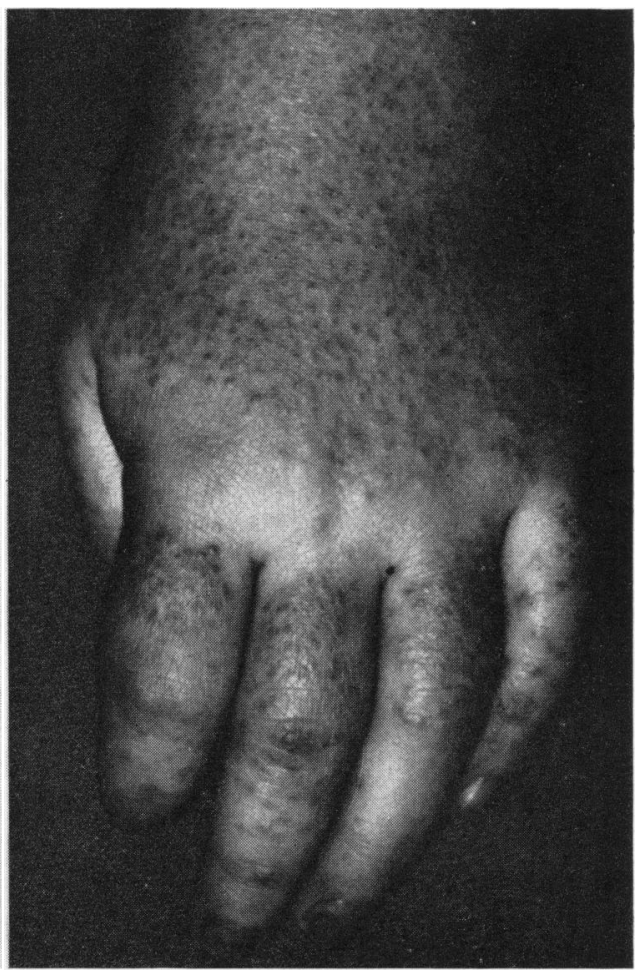

Fig. 2.-Papules on the hands and ballooning of the proximal phalanges of the fingers.

tioned the presence of swollen hands in one of his first publications on sarcoidosis. It is quite possible that they were caused by bone sarcoidosis.

Fusiform swelling of the fingers without radiological evidence of cystic alterations of the phalanges, as seen in our patient, was also noted by Holt and Owens (1949). Burman and Mayer (1936) ascribed the conical form of the fingers of their patients to proliferation of the soft tissues around the proximal phalanges. Persistent polyarthritis is a rare manifestation of the disease (Putkonen, Virkkunen, and Wager, 1965).

In the adult cases and in the child reported by Zweifel no capsule biopsy was performed; in the case of Burman and Mayer (1936) a biopsy was performed at arthroscopic examination. Castellanos and Galan (1946) mentioned a case of a 3-yearold boy with arthritis of the knee, where the diagnosis was verified by muscle biopsy. As this case was furthermore complicated by active tuberculosis, it is not certain that the arthritis was actually due to sarcoidosis.

Clinical appearance of the skin lesions. Very small papules in sarcoidosis are also very uncommon, 


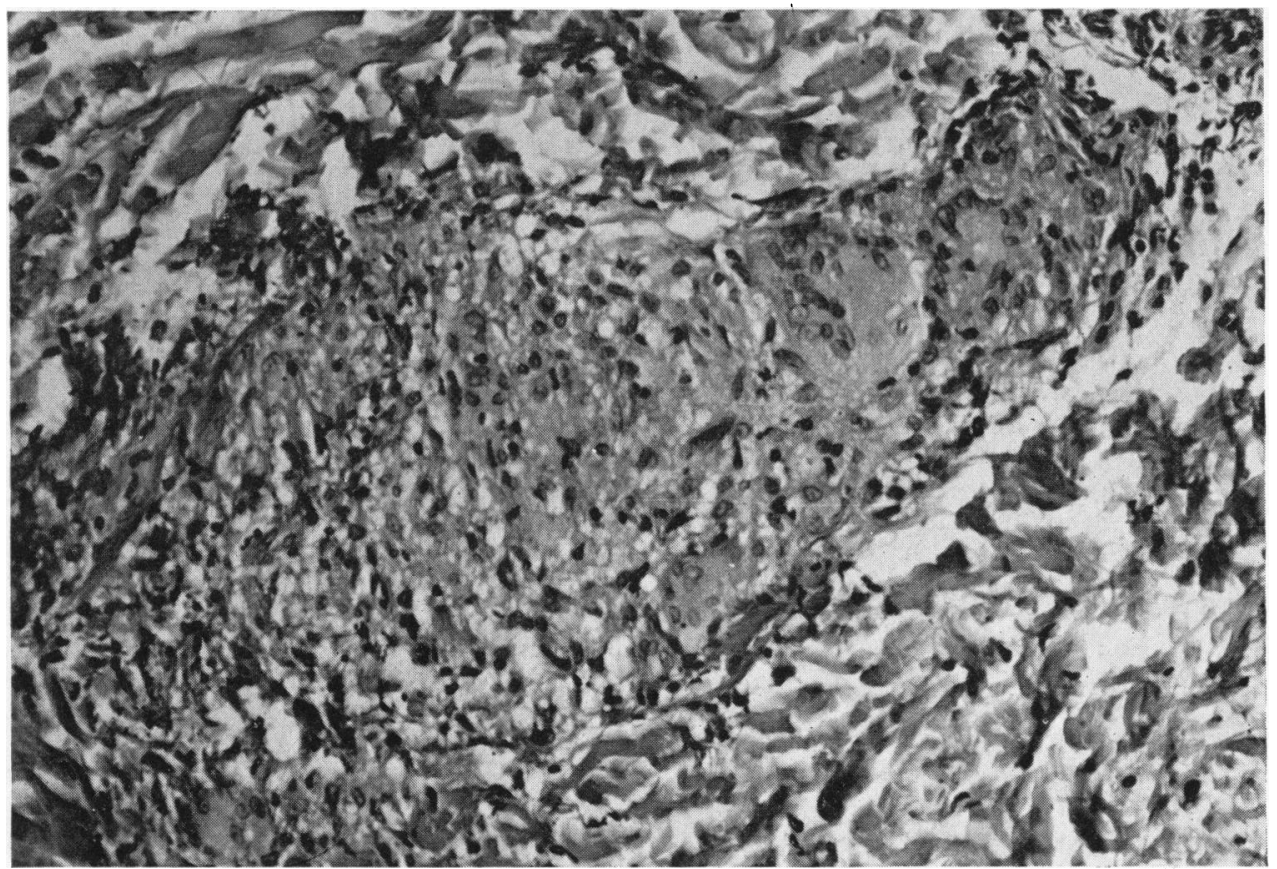

Fig. 3.-Granuloma in the cutis, consisting of epithelioid cells, some giant cells, and a few lymphocytes ( $\times$ 584).

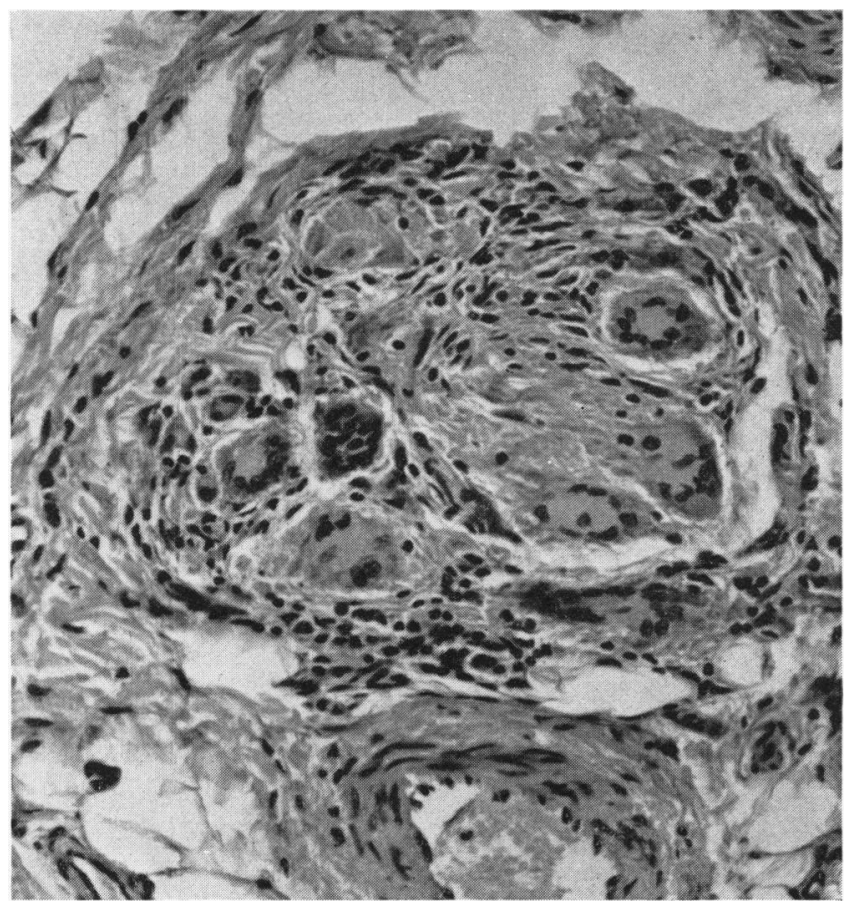

Fig. 4.-Small granuloma with many giant cells in the biopsy from the knee capsule ( $\times 590)$. 


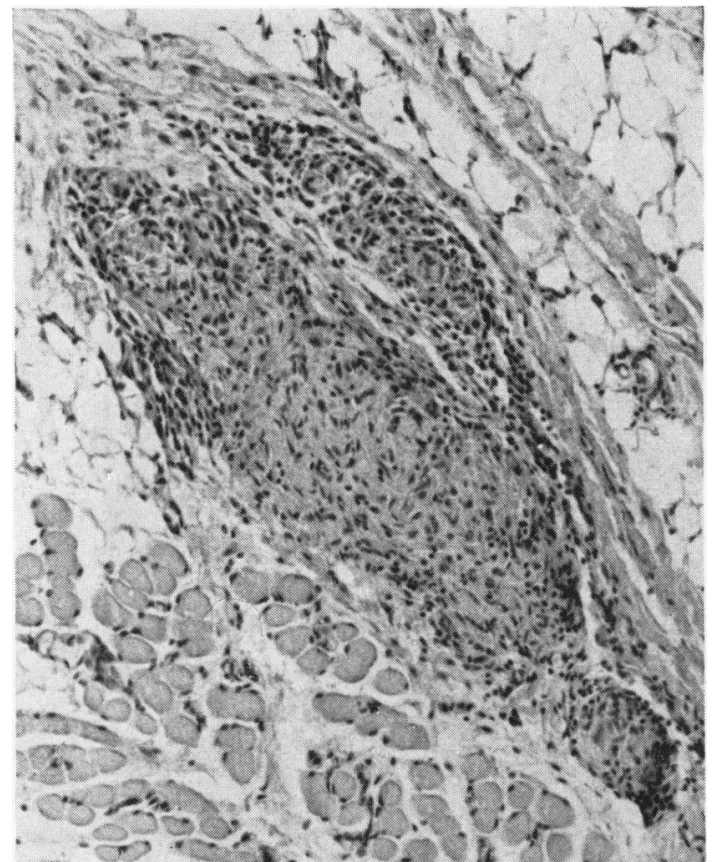

Fig. 5.-Granuloma in the biopsy from the knee capsule $(\times 310)$.

but have been described (Hallopeau and Eck, 1902; Wolf, 1946).

\section{Summary}

A case of sarcoidosis of the joints and skin in a 2-year-old boy is described. The diagnosis was established by biopsies of skin and knee-joint capsule. The clinical symptoms responded to prednisone. Iridocyclitis occurred as a late symptom 3 years after the onset of the disease.

The boy's brother has recently developed sarcoidosis of the skin.

\section{REFERENCES}

Besnier, E. (1889). Lupus pernio de la face; synovites fongueuses symétriques des extrémités supérieures. Ann. Derm. Syph. (Paris), 10, 333.

Burman, M. S., and Mayer, L. (1936). Arthroscopic examination of the knee-joint. Arch. Surg., 32, 846.

Castellanos, A., and Galan, E. (1946). Sarcoidosis (Besnier-BoeckSchaumann's disease). Report of a case in a child, simulating Still's disease. Amer. F. Dis. Child., 71, 513.

Hallopeau, H., and Eck, J. (1902). Contribution à l'étude des sarcoides de Boeck. Ann. Derm. Syph. (Paris), 3, 985.

Holt, J. F., and Owens, W. I. (1949). The osseous lesions of sarcoidosis. Radiology, 53, 11.

Kaplan, H. (1963). Sarcoid arthritis. Arch. intern. Med., 112, 924.

Katsman, A. (1953). Polyarthritis and erythema nodosum in sarcoidosis. N.Y. St. F. Med., 53, 1459.

Kendig, E. L., Jr. (1962). Sarcoidosis among children. F. Pediat., 61, 269.

McGovern, J. P., and Merritt, D. M. (1956). Sarcoidosis in childhood. Advanc. Pediat., 8, 97.

Moreau, R. (1949). Formes articulaires de la maladie de BesnierBoeck-Schauman. Bull. Acad. nat. Méd. (Paris), 133, 89.

Myers, G. B., Gottlieb, A. M., Mattman, P. E., Eckley, G. M., and Chason, J. L. (1952). Joint and skeletal muscle manifestations in sarcoidosis. Amer. F. Med., 12, 161.

Putkonen, T., Virkkunen, M., and Wager, O. (1965). Joint involvement in sarcoidosis with special reference to the coexistence of sarcoidosis and rheumatoid arthritis. Acta rheum. scand., 11, 53.

Regniers, P. (1963). Polyarticulair lijden. Belg. T. Geneesk., 19, 1. Wolf, J. (1946). Lichenoid sarcoid. Arch. Derm. Syph. (Chic.), $54,765$.

Zweifel, S. (1946). Gleichzeitiges Vorkommen eines Boeckschen Sarkoids mit einer primären chronischen Polyarthritis (beginnendes Sjögren Syndrom). Helv. paediat. Acta, 1, 475. 